\title{
Morphological effects on the water balance of Antarctic foliose and fruticose lichens
}

\author{
A.H.L. HUISKES', N.J.M. GREMMEN² and J.W. FRANCKE' \\ ${ }^{\prime}$ Netherlands Institute of Ecology, Centre for Estuarine and Coastal Ecology, Vierstraat 28, 4401 EA Yerseke, The Netherlands \\ ${ }^{2}$ Bureau Data-Analyse Ecologie, Erf 10, 6641 VS Beuningen, The Netherlands
}

\begin{abstract}
Uptake and loss of water by six lichen species from the Argentine Islands, Antarctic Peninsula, were studied in their natural habitat and in laboratory studies. Under field conditions, during a period of rain, uptake of moisture ranged from $15 \% \mathrm{~d} \mathrm{w} \mathrm{h}^{-1}$ for Usnea antarctica to almost $90 \%$ for Mastodia tesselata. Loss rates after the rain ceased were lower than the uptake rates and ranged from $8.5 \% \mathrm{~d} \mathrm{w} \mathrm{h}^{-1}$ in Umbilicaria decussata to $38.8 \%$ in $M$. tesselata. A comparison of thalli of $M$. tesselata from the shoreline with thalli collected further inland showed significant differences in maximum water content and in rates of water loss and uptake between thalli from these sites, which could be ascribed to the presence of salt in the thalli of $M$. tesselata from the shore. Thallus samples of Usnea antarctica collected from an exposed site showed lower uptake rates and higher loss rates of water than samples collected from a more sheltered site. Under laboratory conditions the maximum moisture content ranged from $67 \%$ in Usnea antarctica to $391 \%$ in M. tesselata. Exposed to an atmosphere of c. $40 \%$ relative humidity and c. $15^{\circ} \mathrm{C}$, lichen thalli lost their water during the first hour of the experiment at rates ranging from $34 \%$ of the maximum moisture content in Umbilicaria propagulifera to $70 \%$ in $U$. decussata. Rates of water loss diminished with time, and after 4-6 hours equilibrium was reached, with water contents of $14-16 \%$ of thallus dry weight The microclimate is the driving force for the thallus water regime. Specific differences in rates of water loss and water uptake depend on the morphology and anatomy of the lichen thalli. The results of the laboratory experiments agree with those from the field study. However, local differences in microclimatic or other environmental factors can be responsible for significant differences in the water regime of thalli of the same species, a result which can only be obtained from field studies.
\end{abstract}

Received 18 December 1995, accepted 22 October 1996

Key words: air humidity, lichens, morphology, rain, water loss, water uptake

\section{Introduction}

Lichen physiology is closely tied to the moisture status of the thallus (e.g. Kershaw 1985, Kappen et al. 1987, 1988, V.R. Smith 1988, and others). As lichens are poikilohydric - they do not appear to have active ways to influence water uptake or loss (Henssen \& Jahns 1974) - thallus water content is strongly related to microclimatic conditions (Bölter et al. 1989). As a consequence water availability is regarded as a very important factor determining the distribution of lichens on a regional as well as on a local scale (Kappen 1985a, Longton 1988, Melick et al. 1994, R.I.L. Smith 1988). Hancock \& Seppelt (1988) suggested that lichen species might exhibit niche specificity related to moisture availability.

Size, morphology and anatomy of the lichen thallus may influence the rates of water uptake and loss (Larson \& Kershaw 1976, Larson 1979, 1981, 1984, Snelgar et al. 1981, Jahns 1984, Harrisson et al. 1986, 1989, Hancock \& Seppelt 1988, Sancho \& Kappen 1989, Hestmark 1992). In some of these studies size and shape of the thallus were determined using morphological or anatomical parameters or more elaborate methods to determine surface to weight ratio (Larson and Kershaw 1976, Larson 1979, 1981, 1984).

Many laboratory studies on the water relations of lichens have been performed by spraying the thalli (e.g. Kappen et al. 1980, Snelgar et al. 1981, Kappen 1985b, Lange \& Kilian 1985 ), by applying artificial rain or fog in a wind tunnel (Larson 1979, 1981, 1984) or by placing the thalli in an environment with controlled air humidity (e.g. Kappen \& Redon 1987, R.I.L. Smith 1988).

Relatively few studies deal with water relations of lichens in natural habitats (Heatwole 1966, Lange et al. 1970, Kershaw \& Rouse 1971, Jahns \& Ott 1983) and even fewer have been performed in Antarctic habitats (Kappen 1983, Kappen et al. 1981).

In this paper we compare laboratory and field data on changes in water content of foliose and fruticose species to assess if laboratory data are a good guide to field performance. In addition the water uptake and loss rates are related to the morphology of the species using simple morphometric parameters. 


\section{Materials and methods}

The study was undertaken during the summer of 1990/91 at the British Antarctic Survey Faraday Station on Galindez Island (Argentine Islands, $65^{\circ} 15^{\prime} \mathrm{S}, 64^{\circ} 16^{\prime} \mathrm{W}$ ). For a general description of the geography and climate of the islands see Smith \& Corner (1973) and Gremmen et al. (1994).

For both the field and the laboratory studies samples of four foliose and two fruticose species (Table I) were collected from a rock outcrop with well developed lichen vegetation $10 \mathrm{~m}$ away from the shoreline and $50 \mathrm{~m}$ NE of Faraday Station. All six species were collected from the north facing slope with an additional collection of Usnea antarctica from the south facing slope.

For the laboratory study samples of two additional fruticose species, (Usnea aurantiaco-atra and Pseudephebe minuscula), were collected near Woozle Hill, Galindez Island, $30 \mathrm{~m}$ above sea level and about $200 \mathrm{~m}$ from the shoreline. These were not included in the field study, as the distance of this site from the laboratory precluded rapid processing of the samples. Additional samples of Mastodia tesselata were collected from a site strongly influenced by sea spray about $2 \mathrm{~m}$ above main sea level and $5 \mathrm{~m}$ away from the shoreline (Table I).

\section{Field studies}

To measure field water content samples were lightly shaken to remove excess water, weighed immediately, and again after drying at $80^{\circ} \mathrm{C}$ to constant weight. However, processing limitations meant that there are not data for all species at each sample time. Five replicates of each of the species were collected every two hours except during periods of precipitation. Because of this a statistical analysis was not possible; only standard errors of the mean are reported.

Meteorological data from the Station provided relative humidity of the air, periods of precipitation and wind speed.

\section{Laboratory experiments}

To establish rates of water uptake and loss some 20 thallus samples of different sizes of each species were collected from different places within the community. Extremely stunted thalli, thalli from very sheltered sites, very small or unusually large thalli were avoided. Extraneous matter was carefully removed and each sample was attached to a thin metal wire, carrying a numbered label. The samples were then placed in a transparent container with a saturated atmosphere. After one day the thalli were weighed on a Sartorius 1475-MP8 electronic balance, and placed in a room at $30-40 \% \mathrm{RH}$, and $12-17^{\circ} \mathrm{C}$. The thalli were weighed after $0.5,1,1.5,2,3,6$, 12 and $24 \mathrm{~h}$. After 24 hours the thalli were placed in a humid chamber at $95-100 \% \mathrm{RH}$ and $10^{\circ} \mathrm{C}$, and weighed again after 24,48 , and in some cases after $160 \mathrm{~h}$. Finally dry weight was determined after drying in an oven at $80^{\circ} \mathrm{C}$ to constant weight.

The significance of differences between each two species was tested using ANOVA.

\section{Morphometrical measurements}

The ratio between thallus surface area and thallus volume was determined for all species. The lichen thalli were modeled as cylinders. The surface area of the lichen was estimated as the sum of the upper surface projection, the

Table I. List of species studied, with short notes on their morphology and the collection sites.

\begin{tabular}{|c|c|}
\hline Species name & Short description \\
\hline Mastodia tesselata (Hook.f. et Harv.) Hook.f. et Harv. & $\begin{array}{l}\text { Foliose thallus, polyphyllous, up to } 1.5 \mathrm{~cm} \text { in diameter. Collected from a population about } \\
2 \mathrm{~m} \text { from the shoreline and from the north facing slope of the rock outcrop, further inland. }\end{array}$ \\
\hline Pseudephebe minuscula (Nyl. ex Arnold) Brodo et Hawksw. & $\begin{array}{l}\text { Fruticose thallus, consisting of very thin branches, forming dense mats. Collected for } \\
\text { laboratory experiments only, from a north facing slope at Woozle Hill, Galindez Island. }\end{array}$ \\
\hline Pseudephebe pubescens (L.) Choisy & $\begin{array}{l}\text { Fruticose thallus, consisting of thin branches, loosely entangled. Collected for field and } \\
\text { laboratory studies from the north facing slope of the rock outcrop. }\end{array}$ \\
\hline Umbilicaria decussata (Vill.) Zahlbr. & $\begin{array}{l}\text { Foliose thallus, uniphyllous, up to } 3 \mathrm{~cm} \text { in diameter, without rhizines. Collected for field } \\
\text { and laboratory studies from the north facing slope of the rock outcrop. }\end{array}$ \\
\hline Umbilicaria propagulifera (Vain.) Llano & $\begin{array}{l}\text { Foliose species, polyphyllous, up to } 3 \mathrm{~cm} \text { in diameter, ventral surface densely covered by } \\
\text { thizines. Collected for field and laboratory studies from the north facing slope of the rock } \\
\text { outcrop. }\end{array}$ \\
\hline Umbilicaria antarctica Frey et Lamb & $\begin{array}{l}\text { Foliose species, uniphyllous, up to } 30 \mathrm{~cm} \text { in diameter, ventral side partly covered by } \\
\text { rhizines. Collected for field and laboratory studies from the north facing slope of the rock } \\
\text { outcrop. }\end{array}$ \\
\hline Usnea antarctica Du Rietz & $\begin{array}{l}\text { Fruticose thallus. Collected for field and laboratory studies from both the north facing and } \\
\text { south facing slope of the rock outcrop. }\end{array}$ \\
\hline Usnea aurantiaco - atra (Jacq.) Bory. & $\begin{array}{l}\text { Fruticose thallus. Collected for laboratory studies only from a north facing slope at Woozle } \\
\text { Hill, Galindez Island. }\end{array}$ \\
\hline
\end{tabular}


lower surface projection and the surface of the sides of the hypothetical cylinder (in case of a flat thallus the height of the cylinder was the thickness of the thallus). For Umbilicaria propagulifera the lower surface area was multiplied by two, an estimate for the surface increase due to the rhizoids and based on microscopical investigations. Five to ten measurements on randomly chosen cross sections of watersaturated thalli were made, the mean being used as an estimate of thallus thickness.

\section{Results}

\section{Field observations}

Data on the water content of the thalli in the field during the four day period are given together with the relative humidity and the periods of precipitation in Fig. 1. Mean wind speed during the observation period was high $\left(12 \mathrm{~m} \mathrm{~s}^{-1}\right)$, gradually declining to $1 \mathrm{~m} \mathrm{~s}^{-1}$ at the end of the wet period, after which the wind speed increased again to $12 \mathrm{~m} \mathrm{~s}^{-1}$ by the end of the observation period.

Initially the lichen thalli were relatively dry, with moisture contents mostly between $20-25 \%$ of dry weight. Just after $14 \mathrm{~h} 00$ on 13 February light rain began, and the water content of all species increased rapidly, until saturation seemed to be reached at $18 \mathrm{~h} 00.14$ and 15 February were days with nearly continuous light rain, sleet or snow. Regular two-hourly observations were resumed on 16 February, a dry, but mostly overcast day. With a cessation of precipitation, the thalli dried out within a few hours (Fig. 1). Maximum water contents were highest in Mastodia tesselata from the shoreline and lowest in Usnea antarctica. Usnea antarctica from the north face of the outcrop showed a more rapid fluctuation in water content than thalli collected from the south facing slope. Rates of water loss and uptake in $M$. tesselata were approximately twice as high in the shoreline population as in the more inland population. Minimum water contents of thalli during the observation period varied between $15 \%$ (Pseudephebe pubescens) and 52\% (M. tesselata).

\section{Laboratory studies}

The water loss of saturated lichen thalli during 12 hours of exposure to a desiccating atmosphere is shown in Fig. 2. The
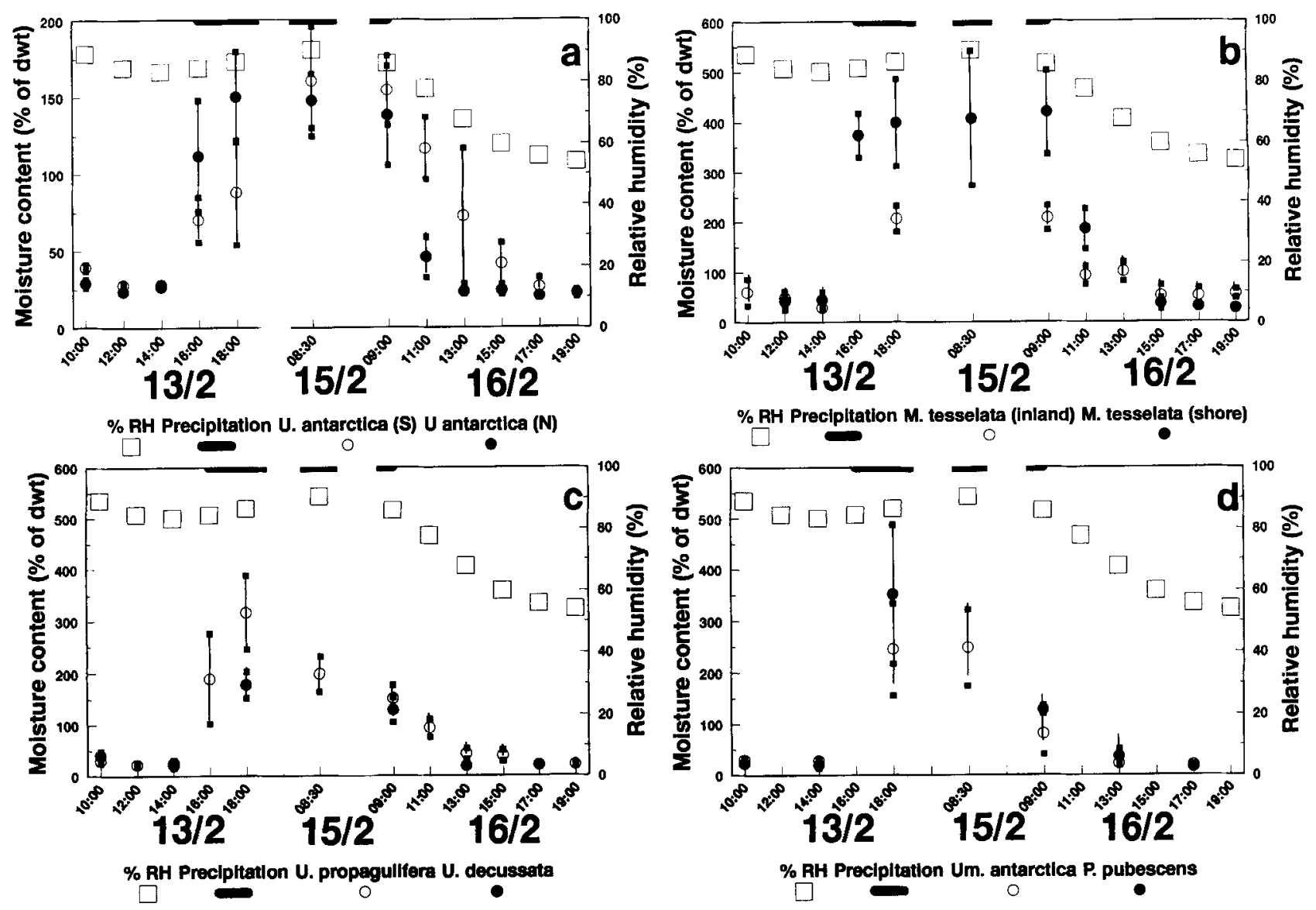

Fig. 1. Moisture content (in \% of dry weight) of thallus samples of different lichen species collected at different times from the rock outcrop. The symbols represent the mean of five samples; the vertical bars represent two standard errors and give the $95 \%$ confidence interval of the mean.\% RH measured at the meteorological observatory. 

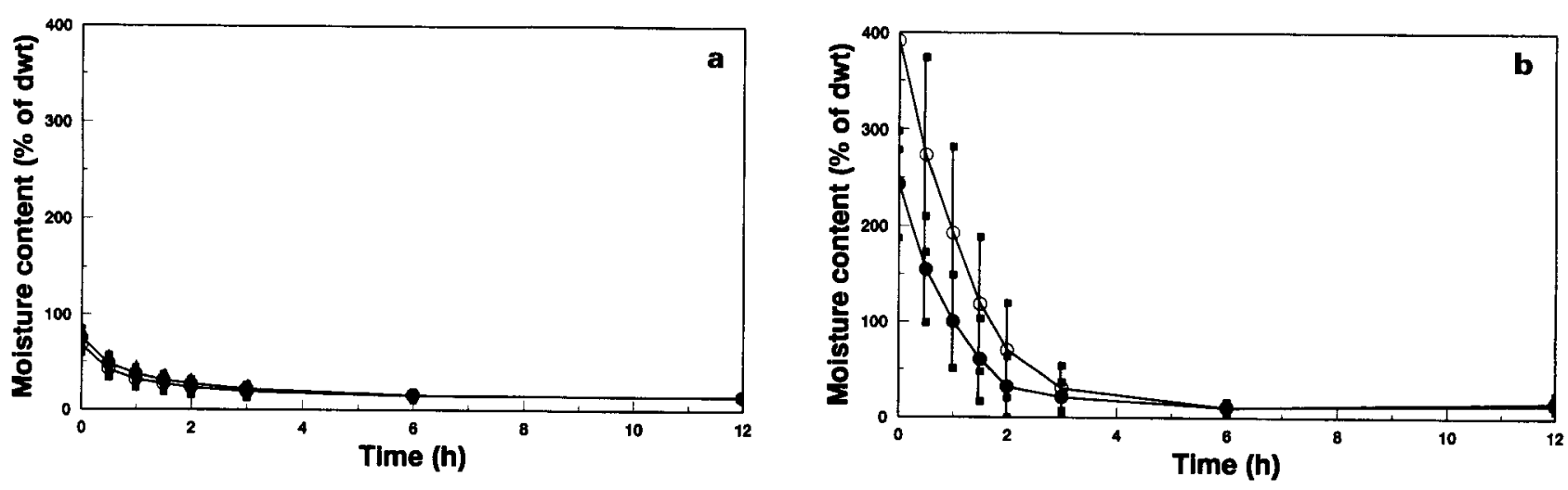

U. aurantiaco - atra U. antarctica

M. tesselata (InI) M. tesselata (sh)

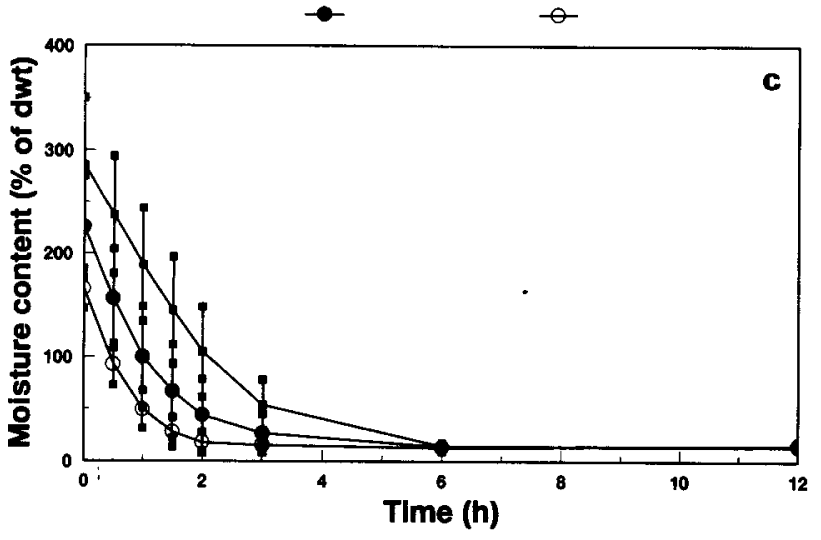

Um. antarctica U. decussata U. propagulifera

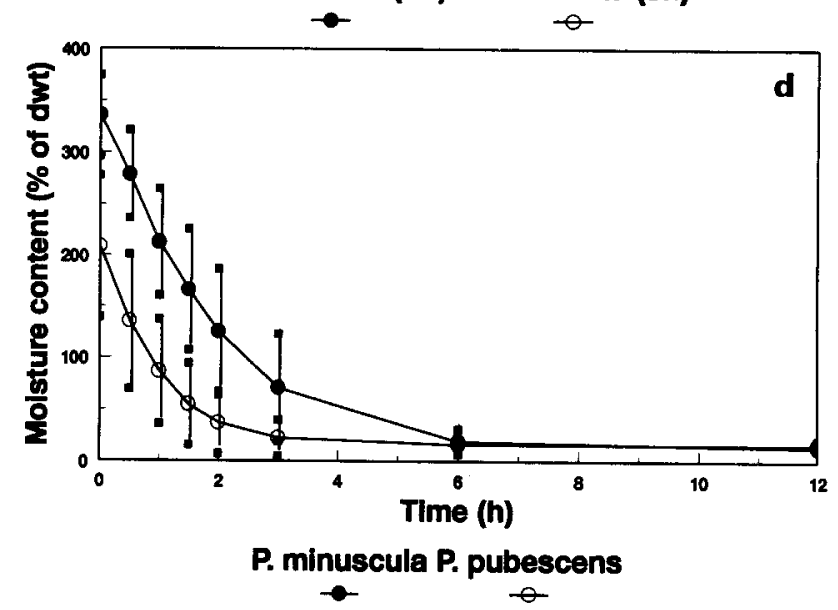

Fig. 2. Water loss of lichen thalli (averages of 15-20 thalli) under laboratory circumstances during exposure to a desiccating atmosphere. The vertical bars indicate two standard errors and give the $95 \%$ confidence intervals of the mean values.

initial water content of the lichen thalli, assumed to be their saturation water content, varied considerably between the species: from c. $67 \%$ in Usnea antarctica to almost $400 \%$ in the shore samples of Mastodia tesselata.

Some species dried out rapidly, notably $M$. tesselata, Umbilicaria decussata and Pseudephebe pubescens, reaching equilibrium with the atmosphere in 2-3 h. All species reached an equilibrium water content in $c .6 \mathrm{~h}$. The equilibrium water content of $14-16 \%$ was similar for all species. Initial water loss was highest in $U$. decussata (over $70 \%$ of the initial water content was lost in the first hour), and lowest in U. propagulifera and Pseudephebe minuscula (34\% and $37 \%$ ). The other species lost c. 50\% of their initial moisture content during the first hour.

The dessication experiment had to be undertaken as two experiments for reasons of space. The first used both Usnea species and both Pseudephebe species were studied whilst the Umbilicaria species and the two populations of $M$. tesselata were measured in the second experiment. Temperature and RH for the two experiments were sufficiently different to limit a statistical comparison of the species to each experiment. The results of the significance tests, using a repeated measures ANOVA showed significant differences in the desiccation between all pairs of species $(P<0.01)$ except that the difference between the curves of Usnea antarctica and of $U$. aurantiaco - atra was only justsignificant $(P=0.03)$.

Water uptake by lichen thalli during the first $24 \mathrm{~h}$ of exposure to the saturated atmosphere ranged from $18 \%$ (for Pseudephebe minuscula) to $26 \%$ (forUmbilicaria antarctica). Rates of water uptake decreased with time and the thalli had not regained their saturated water content even after $160 \mathrm{~h}$.

The relation between surface area to volume ratio and water uptake and loss is shown in Table II. The table is arranged in decending order of surface/volume ratio. As the water uptake and loss rates followed in most cases an exponential function, the water contents were converted into logarithmic values. In Table II water uptake and loss rates are shown over the complete uptake and desiccation period. All species show higher water loss rates in the laboratory experiment as compared to those determined in the field study, except for the water loss rate of Usnea antarctica from the north face of the rock which is higher than the water loss rate in the field. The rates of water uptake in the field are all higher than the loss rates. Pseudephebe minuscula has the highest surface/volume ratio and shows an average water loss 
Table II. Ratio of surface area to volume, moisture uptake and loss rates in the field and loss rates in the laboratory experiment for the lichen species studied. Experimental data expressed as natural logarithms of rate per hour.

\begin{tabular}{|c|c|c|c|c|}
\hline Species(habitat) & $\begin{array}{l}\text { urface/volume } \\
\text { ratio }\end{array}$ & $\begin{array}{l}\text { field expt. } \\
\text { moisture } \\
\text { uptake }\end{array}$ & $\begin{array}{l}\text { field expt. } \\
\text { moisture } \\
\text { loss }\end{array}$ & $\begin{array}{l}\text { lab expt. } \\
\text { moisture } \\
\text { loss }\end{array}$ \\
\hline Pseudephebe minuscula & 33.4 & & & 0.53 \\
\hline Pseudephebe pubescens & 26.7 & 0.79 & 0.27 & 0.86 \\
\hline Mastodia tesselata (inland) & 25.8 & 0.31 & 0.21 & 0.47 \\
\hline Mastodia tesselata (shore) & 20.8 & 0.56 & 0.37 & 0.53 \\
\hline Usnea aurantiaco - atra & 20.1 & & & 0.28 \\
\hline \multirow[t]{2}{*}{ Usnea antarctica $(\mathrm{N})$} & & 0.40 & 0.39 & \\
\hline & 14.3 & & & 0.26 \\
\hline Usnea antarctica $(\mathrm{S})$ & & 0.46 & 0.19 & \\
\hline Umbilicaria propagulifera & 13.8 & 0.69 & 0.25 & 0.50 \\
\hline Umbilicaria antarctica & 11.8 & 0.57 & 0.35 & 0.46 \\
\hline Umbilicaria decussata & 5.3 & 0.55 & 0.47 & 0.78 \\
\hline
\end{tabular}

rate in the laboratory experiment. $P$. pubescens, with a lower, but still comparatively high surface/volume ratio, has a relatively high uptake rate in the field experiment, a relatively low loss rate in the field experiment, and a relatively high loss rate in the laboratory experiment. A comparison of the Umbilicaria species shows that $U$. decussata with the lowest surface - volume ratio shows relatively high uptake and loss rates in the field and a high loss rate in the laboratory experiment. The otherUmbilicaria species show a higher uptake rate of water in the field study when the surface to volume ratio is higher, the loss rates in the field show an opposite reaction. The $U$ snea species show relatively low loss rates in the laboratory. Under field circumstances differences in uptake and loss rate were found for the north and south facing slope.

The samples from the two Mastodia populations showed differences, both in surface/volume ratio as well as in uptake and water loss rates. In the inland population with the higher surface/volume ratio lower uptake - and loss rates were found.

\section{Discussion}

With one exception maximum and equilibrium water contents in this study agree with data presented by R.I.L. Smith (1988) and Sancho \& Kappen (1989) (Table III). However the maximum water content of $260 \%$ reported by Sancho \& Kappen (1989) for Umbilicaria decussata is about twice the value found in this study and by R.I.L. Smith (1988). We have no explanation for this difference.

In the field there was a rapid response of thallus water content to changes in water availability in the lichen's environment. Although water uptake and loss is largely synchronous between species, and likely to be governed by the microclimatic circumstances, the rates at which this occurs differ widely. These rates have been shown to be strongly dependent on the morphology and size of the thallus
Table III. Minimum and maximum thallus water content figures reported in the literature. Sources are: 'RIL Smith 1988, ${ }^{2}$ Sancho \& Kappen 1989, ${ }^{3}$ Kappen 1985a, ${ }^{4}$ Kappen $1985 b$.

\begin{tabular}{lcccc}
\hline & \multicolumn{2}{c}{ laboratory } & \multicolumn{2}{c}{ field } \\
& maximum & minimum & maximum & minimum \\
\hline Pseudephebe minuscula & $350^{1}$ & $12^{1}$ & $340^{1}$ & $11^{1}$ \\
Umbilicaria decussata & $130^{1}$ & $14^{1}$ & $140^{1}$ & $12^{1}$ \\
& $260^{2}$ & $18^{2}$ & $151^{3}$ & \\
Usnea antarctica & $85^{1}$ & $15^{1}$ & & \\
Usnea aurantiaco - atra & & & $164^{4}$ & \\
\hline
\end{tabular}

(Larson \& Kershaw 1976, Larson 1979, 1981, 1984, Rundel 1982, Lange \& Kilian 1985). Larson (1981) found an increase in water uptake rate with increasing surface to weight ratio in 11 species of lichens using microscopic glass beads adhering to the moist thallus surface to determine the surface area of the thallus. Snelgar \& Green (1981) and Rodgers (1976) found similar relationships, but within a collection of thalli from a single species. Our results show for Pseudephebe pubescens, with a relatively high surface to volume ratio, a relatively high rate of moisture uptake rate and a relatively low rate of moisture loss under field circumstances. For Umbilicaria antarctica and $U$. propagulifera with lower surface to volume ratios uptake rates were relatively lower and loss rates were higher. These species follow the expected trends between surface to volume ratios and water relations. $U$. decussata, with the lowest surface to volume rate and an uptake rate similar to that of $U$. antarctica but with a higher moisture loss rate in the field, does not. Thalli of Usnea antarctica collected from the south facing slope showed higher uptake rates and lower loss rates as compared to thalli collected from the north facing slope, although their surface to volume ratio was similar. This difference can only be ascribed to the differences in water availability on both slopes, the north facing slope being the more exposed.

We found significant differences betweenthalli of Mastodia tesselata. Despite the differences in morphology of the thalli of the two populations they, nevertheless, belonged to the species $M$. tesselata (D.O. Øvstedal, personal communication). Thalli exposed to sea water contained $200-400 \mathrm{mmol} \mathrm{Cl}^{-1} \mathrm{~kg}^{-1}$ while thalli from the more inland population contained only $2-4 \mathrm{mmol} \mathrm{Cl} \mathrm{kg}^{-1}$. The thalli with the higher salt content showed a rapid uptake of water probably because of the hygroscopic nature of the salt, and a retarded moisture loss (as shown in the laboratory experiment Fig. 1b). The higher water loss rate in the field in comparison with the water loss rate in the inland population, might be due to the rain washing out most of the salt, resulting in a higher water loss rate which was more in agreement with the differences in surface/volume ratio of the thalli of both populations. Maximum field moisture content of the thalli from the shore population was twice that of the thalli from the rock outcrop. These findings agree with the results presented by Follmann (1967) and Nash III et al. (1979) describing the 
hygroscopic action of salt in thalli from the sea shore.

For most species the maximum water content found in the field is similar to that found in the laboratory experiments (cf. Figs $1 \&$ 2). Exceptions are P. pubescens and Usnea antarctica, where maximum field water contents are c. $50 \%$ and $100 \%$ higher than those attained under laboratory conditions. These maximum field water contents were observed during rain. In the foliose Umbilicaria and Mastodia presumably the light shaking given to the thalli upon collection was sufficient to remove rain or melting snow. In the fruticose Usnea antarctica and $P$. pubescens it is possible that not all external water was removed.

The lower relative humidity of the air in the laboratory experiment probably accounts for the higher minimum water contents measured in the field and the higher rates of water loss in the laboratory experiments.

Water uptake in our laboratory experiments was low, much lower than rates reported by Lange et al. (1970) and others (e.g. Kappen 1980, Larson 1981, Kappen 1985b, Kershaw 1985, Lange et al. 1994). In our experiment the lichen thalli were exposed to humid air only. Spraying of the thalli (Kappen et al. 1980, Larson 1981, Kappen 1985b) resulted in a much faster uptake of water. Uptake of water from humid or foggy air can be an extremely slow process exceeding $50 \mathrm{~h}$ (Lange \& Kilian 1985). Compared with these results, the slow uptake of water in the laboratory experiment is not exceptional.

This paper shows that although the microclimate may be the driving force for the water relations in lichens morphological and anatomical differences between thalli may result in distinctly different uptake and loss rates of water. Fruticose and foliose lichen species collected from the same habitat, a north-exposed rock outcrop, showed strong variation in their water uptake and water loss, in the field as well in the laboratory. Rates of uptake also depend on whether uptake is from liquid water or from a saturated atmosphere. With a similar microclimate, the surface to volume ratio of the thalli governed the water relations of the different species but there are still differences which cannot be explained from the findings in this study.

In general comparative studies under laboratory conditions support the same conclusions as the results obtained in field studies. However, comparing samples of a single species (Usnea antarctica) from the exposed north slope and the more sheltered south slope showed the strong influence of the local microclimate on thalli of similar surface to volume ratio, a result that was not clear in the laboratory studies.

\section{Acknowledgements}

This work was funded by the Netherlands Antarctic Research Programme 1989/1993, administered by the Netherlands Organisation for Scientific Research. We wish to express our gratitude to the British Antarctic Survey, for allowing us to use Faraday Station for this research. We are greatly indebted to all members of staff of BAS, both in Cambridge and in the Antarctic, who helped us with the planning and execution of this study. We are grateful for the constructive comments of three annonymous reviewers.

This is publication no. 2192 of the Netherlands Institute of Ecology, Centre for Coastal and Estuarine Ecology, Yerseke, the Netherlands.

\section{References}

BóltzR, M., KAPPEN, L. \& MEYER, M. 1989. The influence of microclimatic conditions on potential photosynthesis of Usnea sphacelata: a model. Ecological Research, 4, 297-307.

Coxson, D.S., Brown, D. \& Kershaw, K.A. 1983. The interaction between $\mathrm{CO}_{2}$ diffusion and the degree of thallus hydration in lichens: some further comments. New Phytologist, 93, 247-260.

FollmanN, G. 1967. Zur Bedeutung der Salzbestaübung für den Wasserhaushalt von Küstenflechten. Berichte der Deutschen Botanischen Gesellschaft, 80, 206-208.

Gremmen, N.J.M., Huiskes, A.H.L. \& Francke, J.W. 1994. Epilithic macrolichen vegetation of the Argentine Islands, Antarctic Peninsula. Antarctic Science, 6, 463-471.

Hancocx, R.J. \& Seppelt, R.D. 1988. Habitat specificity and morphological variation in two Antarctic Usnea species. Polarforschung, 58, 285-291.

Harrisson, P.M., Walton, D.W.H. \& Rothery, P. 1986. The effects of temperature and moisture on dark respiration in the foliose lichen Umbilicaria antarctica. New Phytologist, 103, 443.455.

Harrisson, P.M., Walton, D.W.H. \& Rothery, P. 1989. The effects of temperature and moisture on $\mathrm{CO}_{2}$ uptake and total resistance to water loss in the Antarctic foliose lichen Umbilicaria antarctica. New Phytologist 111, 673-682.

HeATWOLe, H. 1966. Moisture exchange between the atmosphere and some lichens of the genus Cladonia. Mycologia, 58, 148-156.

Henssen, A. \& Jahns, H.M. 1974. Lichenes. Stuttgart: Georg Thierne, $467 \mathrm{pp}$.

Hestmark, G. 1992. Sex, size, competition and escape strategies of reproduction and dispersal in Lasallia pustulata (Umbilicariaceae, Ascomycetes). Oecologia, 92, 305-312.

JAHN, H.M. 1984. Morphology, reproduction and water relations - a system of morphogenetic interactions in Parmelia saxatilis. Beihefte zur Nova Hedwigia, 79,715-737.

JAHNS, H.M. \& OTT, S. 1983. Das Microklima dicht Benachbarter Flechtenstandorte. Flora, 173, 183-222.

KAPPEN, L. 1983. Ecology and physiology of the antarctic fruticose lichen Usnea sulphurea (Koenig) Th. Fries. Polar Biology, 1, 249-255.

KAPPEN, L. 1985a. Vegetation and ecology of ice-free areas of northern Victoria Land, Antarctica. 2. Ecological conditions in typical microhabitats of lichens at Birthday Ridge. Polar Biology, 4, 227.236.

KAPPEN, L. $1985 \mathrm{~b}$. Water relations and net photosynthesis of Usnea. A comparison between Usnea fasciata (maritime Antarctic) and Usnea sulphurea (continental Antarctic). In Brown, D.H., ed. Lichen physiology and cell biology. London: Plenum Press, 41-56.

KAPPEN, L., Bolter, M. \& KüHN, A. 1987. Photosynthethic activity of lichens in natural habitats in the maritime Antarctic. Bibliotheca Lichenologia, 25, 297-312.

KAPPEN, L., FrIEDMANN, E.I. \& GartY, J. 1981. Ecophysiology of lichens in the Dry Valleys of Southern Victoria Land, Antarctica. I. Microclimate of the cryptoendolithic lichen habitat. Flora, 171, 216-235.

Kappen, L., Lange, O.L., Schulze, E.-D., Buschbom, U. \& Evenari, M. 1980. Ecophysiological investigations on lichens of the Negev Desert. VII. The influence of habitat exposure on dew imbibition and photosynthetic productivity. Flora, 169, 216-229. 
KAPPEN, L., MEYER, M. \& BOLTER, M. 1988, Photosynthetic production of the lichen Ramalina terebrata Hook. f. et Tayl. in the maritime Antarctic. Polarforschung, 58, 181-188.

KAPPEN, L., \& REDON, J, 1987. Photosynthesis and water relations of three maritime Antarctic lichen species. Flora, 179, 215-229.

Kershaw, K.A. 1985. Physiological ecology of lichens. Cambridge: Cambridge University Press, 293 pp.

Kershaw, K.A. \& Rouse, W.R. 1971. Studies on lichen-dominated systems. 1 . The water relations of Cladonia alpestris in spruce-lichen woodland in northern Ontario. Canadian Journal of Botany, 49, 1389-1398.

LANGE, O.L. 1980. Moisture content and $\mathrm{CO}_{2}$ exchange of lichens. $\mathrm{I}$. Influence of temperature on moisture-dependent net photosynthesis and dark respiration in Ramalina maciformis. Oecologia, 45, 82-87.

LANGE, O.L. \& KAPPEN, L. 1972. Photosynthesis of lichens from Antarctica. In Llano, G.A., ed. Antarctic terrestrial biology. Antarctic Research Series, 20, 83-95.

Lange, O.L. \& KiLian, E, 1985. Reaktivierung der Photosynthese trockener Flechten durch Wasserdampfaufnahme aus dem Luftraum: Artspezifisch unterschiedliches Verhalten. Flora, 176,7-23.

LANGE, O.L. \& TENhUNEN, J.D. 1981. Moisture content and $\mathrm{CO}_{2}$ exchange in lichens. II. Depression of net photosynthesis in Ramalina maciformis at high water content is caused by increased thallus carbon dioxide diffusion resistance. Oecologia, 51, 426-429.

Lange, O.L., Meyer, A., Zellner, H. \& Hzber, U. 1994. Photosynthesis and water relations of lichen soil crusts: field measurements in the coastal fog zone of the Namib Desert. Functional Ecology, 8, 253-264.

LANGE, O.L., SchulzE, E.-D. \& KoCH, W. 1970. Experimentell-ökologische Untersuchungen an Flechten der Negev - Wüste. II. $\mathrm{CO}_{2} \cdot$ Gaswechsel und Wasserhaushalt von Ramalina maciformis (Del.) Bory am natürlichen Standort während der sommerlichen Trockenperiode. Flora, $159,38-62$.

LARSON, D.W. 1979. Lichen water relations under drying conditions. New Phytologist, 82, 713-731.

LARSON, D.W. 1981. Differential wetting in some lichens and mosses: the role of morphology. Bryologist, 84,1-15.
LARSON, D.W. 1984. Thallus size as a complicating factor in the physiological ecology of lichens. New Phytologist, 97, 87-97.

Larson, D.W. \& Kershaw, K.A. 1976. Studies on lichen dominated systems. XVIII. Morphological control of evaporation in lichens. Canadian Journal of Botany, 54, 2061-2073.

Longton, R.E. 1988. The Biology of Polar Bryophytes and Lichens. Cambridge: Cambridge University Press, $391 \mathrm{pp}$.

Melick, D.R., Hovenden, M.J. \& SEPPELT, R.D. 1994. Phytogeography of bryophyte and lichen vegetation in the Windmill Islands, Wilkes Land, Continental Antarctica. Vegetatio, 111, 71-87.

Nash III, T.H., Nebeker, G.T., Moser, T.J. \& ReEVes, T. 1979. Lichen vegetational gradients in relation to the Pacific coast of Baja California: The marine influence. Madroño, 26, 149-163.

RODGERS, R.W. 1976. Lichens of hot arid and semi-arid lands. In SEWARD, M.R.D., ed.Lichen ecology. New York: Academic Press, pp 211-252.

RUNDEL, P.W. 1982. The role of morphology in the water relations of desert lichens. Journal of the Hattori Botanical Laboratory, $53,315-320$.

SANCHO, L.G. \& KAPPEN, L. 1989. Photosynthesis and water relations and the role of anatomy in Umbilicariaceae (lichenes) from central Spain. Oecologia, 81, 473-480.

SMTTH, R.I.L. 1988. Aspects of cryptogam water relations at a continental Antarctic site. Polarforschung, 58, 139-153.

SMITH, R.I.L. \& CORNER, R.W.M. 1973. Vegetation of the Arthur Harbour - Argentine Islands region of the Antarctic Peninsula. British Antarctic Survey Bulletin, Nos. 33-34, 39-122.

SMiTH, V.R. 1988. Ecophysiology of carbon assimilation and nitrogen fixation in a subantarctic lichen. Polarforschung, 58, 155-170.

SNELGAR, W.P.\& GreEN, T.G.A. 1981. Ecologically linked variation in morphology, acetylene reduction, and water relations in Pseudocyphellaria dissimilis. New Phytologist, 87, 403-411.

SNelgar, W.P., GReEN, T.G.A. \& Wilkins, A.L. 1981. Carbon dioxide exchange in lichens: resistances to $\mathrm{CO}_{2}$ uptake at different water contents. New Phytologist, 88, 353-361. 